\title{
Morbilliviruses in aquatic mammals: report on round table discussion
}

\author{
T. Barrett ${ }^{\mathrm{a}, *}$, M. Blixenkrone-Møller ${ }^{\mathrm{b}}$, G. Di Guardo ${ }^{\mathrm{c}}$, \\ M. Domingo ${ }^{\text {d }}$, P. Duignan ${ }^{e}$, A. Hall ${ }^{f}$, L. Mamaev ${ }^{g}$, \\ A.D.M.E. Osterhaus ${ }^{\text {h }}$ \\ anstitute for Animal Health, Pirbright, Woking GU24 ONF, UK \\ ${ }^{\mathrm{b}}$ Laboratory of Virology and Immunology, the Royal veterinary and Agricultural University, Frederiksberg, \\ Denmark \\ ${ }^{c}$ Instituto Zooprofilattico, Rome, Italy \\ d Department of Veterinary Pathology, Universidad Autónoma de Barcelona, Barcelona, Spain \\ 'Department of Pathology, University of Guelph, Guelph Canada \\ ${ }^{\mathrm{S}}$ Sea Mammal Research Unit, Cambridge, UK \\ ${ }^{\mathrm{g}}$ Limnologiacl Institute, Irkutsk, Siberia, Russia \\ ${ }^{\mathrm{h}}$ Department of Virology, Erasmus University, Rotterdam, The Netherlands
}

Accepted 4 January 1995

\begin{abstract}
A workshop was organised to ascertain the current situation with regard to morbillivirus infections in aquatic animals. The great interest generated by the discovery of these new virus infections in 1988 has to some extent abated but much high quality research has continued in this field as the workshop showed. There is some serological evidence that the viruses have continued to circulate in most areas since the initial epizootics. As to their origin, it appears that the most likely source of the European seal morbillivirus (PDV-1) is the North Atlantic and Arctic seal populations. As to the origin of the Mediterranean dolphin morbillivirus and the morbilliviruses isolated from porpoises, there is serological evidence that the viruses are widespread in many cetacean species in the Atlantic and $93 \%$ of long-finned pilot whales (Globicephala melas) which mass stranded between 1982 and 1993 were morbillivirus seropositive. The epizootic in freshwater seals in Lake Baikal was unrelated to events in the European marine mammal populations. The virus which infected these animals (PDV-2) is indistinguishable from canine distemper field strains. Serological and molecular biological studies provided evidence for the presence of the virus in the seals, at least as late as the Summer of 1992 when the animals were last sampled.
\end{abstract}

Keywords: Pinniped morbilliviruses; Cetacean morbilliviruses; Epizootiology 


\section{Introduction}

Morbillivirus infections in marine mammals were first discovered in 1988 (Osterhaus and Vedder, 1995). Subsequently morbilliviruses were found in Siberian seals (Phoca sibirica), in harbour porpoises (Phocoena phocoena) and striped dolphins (Stenella coeruleoalba) in the Mediterranean Sea (Osterhaus et al., 1995). More recently evidence is emerging of more widesepread seropositivity for morbilliviruses in a variety of marine mammals in the Atlantic (Duignan et al., 1995a). The origin of these viruses remains an enigma, but it is certain that the marine mammal viruses are not recent introductions from the terrestrial environment. In contrast the freshwater seals in Lake Baikal almost certainly were infected by terrestrial carnivores with which they came in contact. The workshop was held in order to draw together the expertise of those working with these viruses to assess the current situation in the various marine mammal populations.

\section{The current situation in European seals}

It was expected, given the small size of the seal populations, that the morbillivirus epizootic in the North Sea would not be maintained. However, there is evidence from the Dutch Waddensea that the virus has continued to persist in seals in that area (Visser et al., 1993). Sera from grey (Halichoerus grypus) and common seals ( Phoca vitulina) collected along the east coast of Britain since 1988 were screened for morbillivirus antibodies using either a CDV neutralisation (VN) test or a PDV ELISA. The results proved equivocal since not all sera were tested under the same conditions. No VN positive juvenile common seals were found in The Moray Firth from 1991 while $40-60 \%$ of the adults were seropositive. Similarly only one juvenile (possibly three years old) out of 25 sampled had a borderline positive VN test. However, using the PDV ELISA sera collected from 75 grey seals from the Farne Islands in 1992 were all found to be seropositive, even from juveniles less than 2 years. Eight of the positive sera were tested in the CDV VN test and found to be negative, highlighting the difficulty of measuring heterologous antibodies in this test. No clinical disease has been seen at any of the rescue centres since 1989 and so the evidence for persistence is solely based on serology. The most likely source of infection for the European seals is likely to have been contact with arctic seal species (most probably the harp seal, Phoca groenlandica) through altered migration patterns in recent years (Dietz et al., 1989) and there is a high prevalance of seropositivity in seals in $\Lambda$ rctic and Canadian waters (Markussen and Have, 1992; Duignan et al., 1995a).

\section{The current situation in Mediterranean cetaceans}

The morbillivirus which killed hundreds of mediterranean dolphins in 1990 has now been well characterised genetically. Partial nucleotide sequence of the phosphoprotein gene showed that it was a new morbillivirus, closely related to a similar virus isolated from

\footnotetext{
${ }^{*}$ Corresponding author.
} 


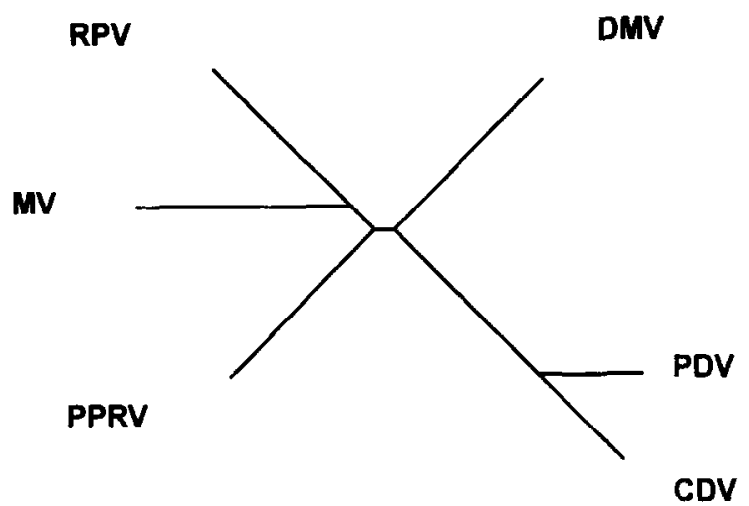

Fig. 1. Phylogenetic tree showing the relationships between the different morbilliviruses based on the sequence of the N gene. The tree was derived using the PHYLIP DNADIST and KITSCH programmes. The branch lengths are proportional to the mutational differences between the viruses and the hypothetical common ancestor that existed at the nodes in the tree.

porpoises but quite distinct from any previously described morbillivirus (Barrett et al., 1993). The complete sequence of the nucleocapsid protein gene (Blixenkrone-Møller et al., 1994) has confirmed this distant relationship to the other morbilliviruses, in contrast to PDV which is obviously more closely related to CDV than to any of the other viruses (see Fig. 1).

Necropsies on striped dolphins stranded along the Catalonian coast from the beginning of the epizootic in summer 1990 to May 1994 have shown a change in the pattern and distribution of lesions and antigen in tissues. After a phase of systemic infections, sporadic disease of chronic encephalitis has been observed, with lesions and morbillivirus antigen restricted to the CNS (Domingo et al., 1995). This is supported by the finding that most striped dolphins, stranded off the Italian coast, which showed evidence of morbillivirus infection, had viral encephalitis. Detailed pathological and virological studies on 25 cetaceans found stranded between 1990 and 1993 off the coast of six Italian regions showed evidence of infection in striped dolphins, one with morbilliviral pneumonia and three with morbilliviral encephalitis. Striped dolphins were the the most common species ( 16 animals ) stranded off the Italian coast, with three each of Tursiops truncatus (bottlenose dolphin) and Grampus griseus (Risso's dolphin) and one each of Steno bredanensis (rough-toothed dolphin), Balaenoptera physalus (fin whale) and Balaenoptera acutorostrata (minke whale). CDV VN antibodies ( titre $=1: 16$ ) were found in the serum of the one adult minke whale which was found stranded off the coast of Tuscany in 1993. No virus was isolated from any of the tissue samples collected from these animals using a variety of cell lines (Vero, MDCK, MDBK, BHK21, RK13 and bovine fetal lung cells) although the poor state of preservation probably was responsible for this failure. Parasitic infections were found in many of the stranded animals $(44 \%)$ while pneumonia $(68 \%)$, enteritis $(44 \%)$, hepatitis $(40 \%)$, nephritis $(32 \%)$ and encephalitis $(32 \%)$ were also common, however, evidence of morbillivirus involvement in the pathological lesions was only found in the four striped dolphins described above.

\section{Current situation in marine mammals from the North American coast}

A wide retrospective serological study of pinnipeds and cetaceans from along the coast of North America (ranging from The Gulf of Mexico to the Arctic) revealed that a significant 
portion were seropositive (Geraci et al., 1993; Duignan et al., 1995b). VN tests were carried out using all known morbilliviruses, including the new viruses isolated from dolphins and porpoises. Highest titres were found to PDV with the seal (harbour, grey, harp and hooded seals (Cystophora cristata) and walrus (Odobenus rosmarus) sera. Sporadic mortality among harbour and harp seals along the coast from Canada to New York has been attributed to morbillivirus-induced pneumonia and encephalitis. Morbillivirus antibodies were found in 129 of 412 odontocetes from regions as far apart as Canada and Texas. The earliest serum was from 1982 and, in the case of the cetacean sera, the highest VN titres were to the dolphin and porpoise morbilliviruses (Duignan et al., 1995a).

\section{Current situation in Lake Baikal seals}

The sequence of the complete haemagglutinin gene of PDV-2, isolated from a Siberian seal ( Phoca sibirica) in 1988 showed that it was most closely related to recent field strains of CDV isolated in Europe. Similar results were found when part of the phosphoprotein gene was analysed. Serological and molecular evidence from samples collected from culled seals (including pups) in the lake in May 1992 showed the continued presence of the virus in the population. Out of 44 sera analysed in a CDV VN test, 11 were positive with titres of 1:80 or greater, and 4 with titres greater than 1:100 (Mamaev et al., 1995). The same sera were also analysed in three different ELISAs using CDV, RPV and PPRV antigens and the same four were also found to be strongly positive. However, there was poor correlation between the VN and the ELISA for the other sera which highlights the great difficulty in establishing baseline negative values in these tests in the absence of true unequivocal negative samples. Analysis of brain tissue from these animals showed that three were positive in a RT/PCR test using universal morbillivirus primers. Sequence analysis of the amplified DNA confirmed that the virus present in the brain was most closely related to PDV-2.

\section{Conclusions}

There is now strong virological, pathological, epidemiological and experimental evidence that morbilliviruses can fatally infect seals (Harder et al., 1992). The question of whether or not PDV has continued to circulate in Northern European waters is open and more precise serological and epidemiological sampling techniques will need to be employed to resolve this question. The main difficulty encountered with studying diseases of wild animals, particularly marine species, is obtaining representative samples from the population. This is only possible where the animals gather on land or ice to breed, as in the case of some seal species.

In the case of cetacean species the situation is less clear since other factors, both pathological and environmental, may also play a part. Reliance on obtaining stranded animals inevitably leads to a biased sampling and attributing the cause of death is very problematical. However, there have been some well documented cases in dolphins where the pathological and virological findings have strongly indicated that the cause of death is a morbillivirus 
infection. Serological evidence suggests that such infections are quite common in a variety of cetacean species and the possibility remains that in most cases infection is sub-clinical.

\section{References}

Barrett, T., Visser, I.K.G., Mamaev, L., Van Bressem, M.-F., and Osterhaus, A.D.M.E., 1993. Dolphin and porpoise morbilliviruses are genetically distinct from phocine distemper virus. Virology, 193: 1010-1012.

Blixenkrone-Møller, M., Bolt, G., Gottschalk, E. and Kentner, M. 1994. Comparative analysis of the gene encoding the nucleocapsid protein of dolphin morbilliviruses. J. Gen. Virol., 75: 2829-2834.

Dietz, R., Ansen, C.T., Have, P. and Heide-Jorgensen, M.-P., 1989. Clue to seal epizootic? Nature, 338: 627.

Domingo, M., Vilafranca. M., Vies, J., Prats, N., Trudgett, A. and Visser, I., 1995. Evidence for chronic morbillivirus infection in the Mediterranean striped dolphin. Vet. Microbiol., Special Issue: Morbilliviruses. Vol. 44.

Duignan, P.J., House, C., Geraci, J.R., Early, H., Copland, M., Walsh, G., Bossart, C., Cray, C., Sadove, S., St. Aubin, D.J. and Moore, M. 1995a. Morbillivinus infection in Pilot whales Globicephala melas and G. macrorhynchus) from the Western Atlantic. Mar. Mammal Sci., in Press.

Duignan, P.J., House, C., Geraci, J.R., Duffy, N., Rima, B.K., Walsh, M.T., Early, G., St. Aubin, D.J., Sadove. S., Koopman. H. and Rhinehart, H., 1995b. Morbillivirus infection in cetaceans of the western Atlantic. Vet. Microbiol, Special Issue: Morbilliviruses, Vol. 44.

, J.R.. Duignan, P.J. and Early, G., 1993. Survey for morbilliviruses in pinnipeds along the northeastern coast. Final report to the National Oceanographic and Atmospheric Administration and National Marine Fisheries Service. Contract no. 50-DGNF-2-00098. 95 pp.

Harder, T.C., Willhaus, T., Leibold, W. and Liess, B., 1992. Investigations on course and outcome of phocine distemper virus infection in harbour seals (Phoca vitulina) exposed to polychlorinated phenols. J. Vet. Med., B, 39: 19-31.

Mamaev, L.V., Denikina, N.N., Belikov, S.I., Volchkov, V.E., Visser, I.K.G., Fleming, M., Kai, C., Harder. T.C., Liess, B.. Osterhaus, A.D.M.E. and Barrett, T.. 1995. Characterisation of morbilliviruses isolated from lake Baikal seals (Phoca sibirica). Vet. Microbiol., Special Issue: Morbilliviruses, Vol. 44.

Markussen, N.H. and Have, P., 1992. Phocine distemper virus infection of harp seals (Phoca groenlandica). Marine Mammal Science, 8: 19-26.

Osterhaus, A.D.M.E. and Vedder, E.J. ( 1988). Identification of virus causing recent seal deaths. Nature, 335: 20.

Osterhaus, A.D.M.E., Swart, R. de., Vos, H.W., Ross, P., Kenter, M.J.H. and Barrett, T., 1995. Morbillivirus infections of aquatic mammals: newly identified members of the genus. Vet. Microbiol., Special Issue: Morbilliviruses, Vol. 44.

Visser, I.K.G., Vedder, E.J., Vos, H.W., van de Bildt, M.W.G. and Osterhaus, A.D.M.E., 1993. Continued presence of phocine distemper virus in the Dutch Wadden Sea seal population, Vet. Rec., 25: 320-322. 